\title{
Pelatihan Kegiatan Penelitian dan Penulisan Karya Ilmiah bagi Guru Madrasah Aliyah Negeri 3 Lombok Tengah
}

\section{Training on Research Activities and Scientific Writing for Madrasah Aliyah Negeri 3 Lombok Tengah Teachers}

Muhali $^{1}$, Muhammad Asy'ari ${ }^{2}$, Saiful Prayogi ${ }^{3}$, Taufik Samsuri ${ }^{4}$, I Wayan Karmana ${ }^{4}$, I Ketut Sukarma ${ }^{5}$, Baiq Mirawati ${ }^{4}$, Laras Firdaus ${ }^{4}$, Hunaepi ${ }^{4 *}$

${ }^{1}$ Prodi Pendidikan Kimia, Fakultas Pendidikan Matematika dan Ilmu Pengetahuan Alam, Institut Keguruan dan Ilmu Pendidikan Mataram, Jl. Pemuda No. 59A Mataram, Indonesia

2 Prodi Pendidikan Olahraga, Fakultas Pendidikan Olahraga dan Kesehatan, Institut Keguruan dan Ilmu Pendidikan Mataram, Jl. Pemuda No. 59A Mataram, Indonesia

${ }^{3}$ Prodi Pendidikan Fisika, Fakultas Pendidikan Matematika dan Ilmu Pengetahuan Alam, Institut Keguruan dan Ilmu Pendidikan Mataram, Jl. Pemuda No. 59A Mataram, Indonesia

${ }^{4}$ Prodi Pendidikan Biologi, Fakultas Pendidikan Matematika dan Ilmu Pengetahuan Alam, Institut Keguruan dan Ilmu Pendidikan Mataram, Jl. Pemuda No. 59A Mataram, Indonesia

${ }^{5}$ Prodi Pendidikan Matematika, Fakultas Pendidikan Matematika dan Ilmu Pengetahuan Alam, Institut Keguruan dan Ilmu Pendidikan Mataram, Jl. Pemuda No. 59A Mataram, Indonesia

\begin{tabular}{l}
\hline Info Artikel \\
\hline Diterima 28 Mei 2019 \\
Ditelaah 1 Juli 2019 \\
Disetujui 27 September 2019 \\
Tersedia daring 30 Oktober \\
2019 \\
*Penulis untuk korespondensi \\
hunaepi@ikipmataram.ac.id \\
\hline
\end{tabular}

Kata Kunci:

Artikel ilmiah

Laporan penelitian

Penelitian tindakan kelas

Publikasi jurnal

Keywords:

Classroom action research Journal publications

Research reports

Scientific articles

\begin{abstract}
ABSTRAK
Tujuan dari kegiatan pengabdian kepada masyarakat ini adalah untuk meningkatkan kemampuan guru dalam melakukan penelitian dan mempublikasikan artikel hasil penelitian pada jurnal ilmiah nasional. Progam ini dilaksanakan melalui serangkaian kegiatan dengan metode in-service training (IST) dan on-service training (OST). Pendekatan andragogis digunakan dalam kegiatan IST untuk meningkatkan kemampuan guru dalam menganalisis permasalahan pembelajaran yang dapat diangkat sebagai permasalahan penelitian; menyampaikan konsep tentang penelitian secara umum, khususnya penelitian tindakan kelas; dan menuliskan laporan penelitian ke dalam bentuk artikel ilmiah. Kegiatan OST dimaksudkan untuk melakukan pendampingan kepada para guru mitra dalam melaksanakan kegiatan penelitian, menulis laporan penelitian dan artikel ilmiah serta melakukan publikasi pada jurnal ilmiah. Hasil kegiatan IST memberikan gambaran keadaan guru Madrasah Aliyah Negeri 3 Lombok Tengah bahwa sebagian besar guru telah mampu menganalisis permasalahan yang dapat diangkat sebagai permasalahan utama pada kegiatan penelitian; guru telah memahami dengan baik tentang konsep penelitian tindakan kelas, desain, instrumen, dan analisis data hasil penelitian; guru telah mampu memahami konsep dan teknik penulisan laporan penelitian dan artikel ilmiah; dan guru telah mampu memahami konsep dan teknik publikasi artikel pada jurnal ilmiah nasional. Hasil OST menunjukkan bahwa guru memiliki potensi untuk mengembangkan diri dalam melakukan penelitian dan menghasilkan karya tulis ilmiah. Selama pelaksanaan kegiatan pengabdian, guru secara konsisten selalu mengikuti kegiatan dengan baik. Karya ilmiah yang dihasilkan dapat dikategorikan baik, dan secara umum telah memenuhi kriteria karya tulis ilmiah.
\end{abstract}

\section{ABSTRACT}

The purpose of this community service was to improve the ability of teachers to conduct research and publish a research article in a national scientific journal. This program was implemented through a series of activities using in-service training (IST) and on-service training (OST) methods. The andragogy approach was used in IST activities to improve the ability of teachers in analyzing the learning problems that can be raised as research problems; to convey the concept of research in general, especially classroom action 


\begin{abstract}
research; and to write a scientific article. OST activities were intended to assist the teachers in conducting research activities, writing research reports and scientific articles and publishing scientific journals. The results of IST activities illustrated the situation of Madrasah Aliyah Negeri 3 Central Lombok teachers that most teachers had been able to analyze problems that can be raised as the main problems in research activities; the teacher had a good understanding of the concept of classroom action research, design, instruments, and analysis of research data; the teacher was able to understand the concepts and techniques of writing research reports and scientific articles; and the teacher had been able to understand the concepts and techniques of publishing articles in national scientific journals. OST results indicated that teachers had the potential to develop themselves in conducting research and producing scientific papers. During the implementation of community service activities, the teacher consistently followed the activities well. The resulting scientific work could be categorized as good, and generally, met the criteria of scientific writing.
\end{abstract}

ISSN 2685-0354 (Media Online). Diterbitkan oleh Universitas Prof. Dr. Hazairin, SH. Ini merupakan jurnal bebas akses di bawah lisensi Creative Commons Atribution 4.0 International (https://creativecommons.org/licenses/by/4.0

\title{
PENDAHULUAN
}

Karya ilmiah merupakan salah satu tuntutan bagi para pendidik, tidak terkecuali bagi guru. Karya ilmiah menjadi syarat wajib bagi guru dalam pengusulan kenaikan kepangkatan. Karya ilmiah guru dapat dibuat melalui kegiatan penelitian di dalam kelas sebagai bentuk upaya perbaikan proses atau tindakan terhadap kelompok peserta didik yang mengalami permasalahan. Penulisan karya ilmiah yang demikian dikenal dengan istilah penelitian tindakan kelas (PTK). Hunaepi et al. (2016) menyatakan bahwa PTK merupakan penelitian yang dapat diakukan guru daam rangka memperbaiki proses-proses pembelajaran untuk mencapai tujuan yang diinginkan. Pelaksanaan PTK sangat relevan dengan fungsi seorang guru sebagai pendidik, pengajar, pembimbing, pelatih, dan evaluator ketercapaian hasil belajar siswa. Dalam konteks ini, PTK dipandang sebagai bentuk penelitian peningkatan kualitas pembelajaran yang paling tepat, karena selain sebagai peneliti, guru juga bertindak sebagai pelaksana proses pembelajaran, sehingga guru tahu betul permasalahan yang dihadapi dan kondisi ideal yang ingin dicapai. Muslich (2011) mendefinisikan PTK sebagai studi yang dilakukan untuk memperbaiki diri sendiri, pengalaman kerja sendiri, yang dilaksanakan secara sistematis, terencana, dan dengan sikap mawas diri.

Guru dituntut untuk terus berupaya meningkatkan kualitas pembelajaran kepada peserta didik melalui berbagai solusi, seperti pengembangan perangkat, perbaikan proses dan hasil pembelajaran (Kementerian Pendidikan dan Kebudayaan, 2013). Upaya tersebut terus dilakukan oleh guru sesuai tingkat perkembangan profesionalitasnya atau tingkat perkembangan peserta didik, tetapi sebagian besar guru tidak menyadari bahwa kegiatan yang dilakukan tersebut merupakan bentuk kegiatan yang dapat ditulis ke dalam karya ilmiah berupa laporan penelitian tindakan kelas atau artikel yang dapat dipublikasi pada jurnal ilmiah.

Tim Pengabdian kepada Masyarakat (PkM) telah melakukan survei kepada sekolah yang telah menjadi mitra dalam pelaksanaan kegiatan pengabdian sebelumnya (Muhali et al., 2019) yaitu Madrasah Aliyah Negeri (MAN) 3 Lombok Tengah, terkait kegiatan guru dalam melakukan kegiatan penelitian. Hasil survei menunjukkan bahwa sebagian besar guru tidak melakukan kegiatan penelitian, sehingga pengusulan kenaikan kepangkatan menjadi terhambat. Jumlah guru di sekolah tersebut sebanyak 48 orang. Sebanyak 10,42\% guru dapat mengusulkan kenaikan pangkat dari golongan III-d ke IV-a (Pembina), dan sisanya sebanyak 35,42\% mengalami hambatan dalam usulan kenaikan kepangkatan ke jenjang III-d, dan 54,16\% ke jenjang IV-a. Data lapangan menunjukkan bahwa hanya ada satu guru yang memiliki artikel ilmiah yang terpublikasi pada jurnal nasional maupun prosiding seminar nasional.

Hasil wawancara tim PkM dengan guru menggambarkan bahwa: (1) guru masih mengalami kesulitan dengan penulisan karya ilmiah, khususnya penelitian tindakan kelas, (2) waktu efektif guru untuk melakukan kegiatan penelitian sangat terbatas karena tuntutan jam wajib untuk memberikan pembelajaran dalam satu minggu sebanyak 24 jam yang dirasakan sangat padat, (3) para guru belum pernah dilatih dalam penyusunan karya ilmiah baik yang diselenggarakan oleh pihak pemerintah terkait maupun pihak lain, (4) kurangnya tingkat kesadaran untuk melakukan kegiatan penelitian dan beranggapan bahwa kenaikan pangkat tidak begitu penting sehingga menjadikan guru enggan untuk melakukan kegiatan tersebut, dan (5) guru mengalami kesulitan untuk melakukan publikasi pada jurnal ilmiah.

Guru adalah subjek yang sangat dekat dengan fenomena yang dialami peserta didik, dan sangat berpeluang untuk mengatasi setiap permasalahan yang dihadapi peserta didik. Menggunakan model, metode, atau pendekatan alternatif untuk perbaikan proses pembelajaran merupakan hal paling sederhana yang sering dilakukan guru dalam pembelajaran di kelas. Dengan melakukan hal demikian, guru telah melakukan penelitian secara prosedural. 
Selanjutnya, hasil penelitian dilaporkan di dalam sebuah laporan penelitian tindakan kelas. Jadi, guru memanfaatkan jam tatap muka sesuai jadwal untuk melakukan pembelajaran sekaligus terintegrasi dengan kegiatan penelitian (Hunaepi et al., 2016). Hasil diskusi tersebut menjadikan guru tertarik untuk melakukan kegiatan penelitian dengan mengintegrasikannya dalam kegiatan pembelajaran sesuai jadwal yang ditetapkan. Pihak sekolah meminta tim PkM untuk melakukan kegiatan pelatihan penyusunan karya ilmiah khususnya PTK.

Tim PkM memberikan pelatihan kegiatan penelitian dan penulisan karya ilmiah dengan tema pelatihan penulisan karya ilmiah dan publikasi bagi guru MAN 3 Lombok Tengah. Seperti yang dilakukan pada tahun-tahun sebelumnya (Prayogi, Sukarma, \& Muhali, 2016; Muhali et al., 2019), dan juga sebagian kecil guru di sekolah tersebut telah terbiasa menulis artikel dan terpublikasi di jurnal ilmiah nasional, sebagai contoh tentang penerapan model problem solving untuk meningkatkan kesadaran metakognisi dan hasil belajar siswa (Sukaisih \& Muhali, 2014), penerapan model guided inquiry dilengkapi penilaian portofolio untuk meningkatkan aktivitas dan hasil belajar fisika siswa (Sukaisih \& Verawati, 2015).

Kegiatan PkM dilakukan dengan memberikan solusi melalui serangkaian kegiatan IST dan OST. Kegiatan IST menggunakan pendekatan andragogis dengan harapan dapat meningkatkan kemampuan guru yaitu: (1) analisis permasalahan pembelajaran yang dapat diangkat sebagai permasalahan penelitian, (2) penyampaian konsep tentang penelitian secara umum, dan khususnya PTK, (3) penyampaian konsep penulisan karya ilmiah.

Kegiatan OST dimaksudkan dengan: (1) melakukan pendampingan kepada para guru mitra dalam melaksanakan kegiatan penelitian, (2) melakukan pendampingan kepada para guru mitra dalam menulis laporan penelitian dan artikel ilmiah, (3) melakukan pendampingan kepada para guru mitra dalam melakukan publikasi pada jurnal ilmiah.

\section{METODE}

Kegiatan PkM ini dilaksanakan selama bulan Agustus 2018 di MAN 3 Lombok Tengah sebagai sekolah mitra yang secara berkelanjutan telah bekerja sama dalam melaksanakan kegiatan pengembangan kualitas pembelajaran dan penelitian. Pelatihan kegiatan penelitian dan penulisan karya ilmiah dilaksanakan dengan menggunakan metode IST dan OST sebagai metode pemecahan permasalahan (Tabel 1).

Tabel 1. Metode Pelaksanaan Kegiatan

\begin{tabular}{|c|c|c|c|}
\hline Solusi & Metode & Materi & Pelaksana/Penyaji \\
\hline \multirow[t]{11}{*}{ IST } & Diskusi & Analisis permasalahan pembelajaran & Tim PkM dan guru mitra \\
\hline & Presentasi, & Konsep tentang penelitian & Dr. Muhali, S.Pd.,M.Sc. \\
\hline & Tanya jawab & Konsep tentang metode penelitian: & \\
\hline & & 1. Desain penelitian & Drs. I Ketut Sukarma, M.Pd. \\
\hline & & 2. Instrumen penelitian & Muhammad Asy'ari, M.Pd. \\
\hline & & 3. Analisis data & Laras Firdaus, S.Pd., M.Pd. \\
\hline & & Konsep penelitian tindakan kelas & Saiful Prayogi, S.Pd., M.Pd. \\
\hline & & Penulisan laporan penelitian & Drs.I Wayan Karmana, M.Pd. \\
\hline & & Konsep penulisan artikel ilmiah & Hunaepi, S.Pd.,M.Pd. \\
\hline & & Publikasi ilmiah & Taufik Samsuri, M.Pd. \\
\hline & & & Baiq Mirawati, M.Pd. \\
\hline \multirow[t]{3}{*}{ OST } & $\begin{array}{l}\text { Pendampingan, } \\
\text { Pelatihan. }\end{array}$ & $\begin{array}{l}\text { Pendampingan pelaksanaan } \\
\text { penelitian. }\end{array}$ & Tim PkM \\
\hline & & Pendampingan penulisan laporan penelitian. & Tim PkM \\
\hline & & $\begin{array}{l}\text { Pendampingan penulisan artikel ilmiah } \\
\text { terpublikasi. }\end{array}$ & Tim PkM \\
\hline
\end{tabular}

\section{Prosedur Pemecahan Masalah}

Tahapan pelaksanan kegitan PKM adalah sebagai berikut:

1. Tahap persiapan. Kegiatan yang dilakukan pada tahapan ini adalah sebagai berikut:

a. Penyusunan Term of Reference (ToR) dari kegiatan PkM yang akan dilaksanakan.

b. Identifikasi calon peserta yang dilibatkan pada kegiatan PkM. Tim PkM melakukan survei dan identifikasi keadaan lapangan untuk mendapatkan data jumlah guru di sekolah mitra yang mengajar mata pelajaran 
matematika, biologi, fisika, dan kimia, serta berkoordinasi dengan Kepala Sekolah terkait peserta yang akan dilibatkan dalam kegiatan.

c. Pertemuan internal tim PkM. Kegiatan ini dilakukan untuk membahas hal-hal seperti: (a) penentuan waktu pelatihan, (b) tempat pelaksanaan kegiatan, (c) sarana dan prasarana yang dibutuhkan selama pelaksanaan kegiatan, (d) pemilihan materi pelatihan, (e) pembagian materi yang akan disampaikan kepada tim pelaksana $\mathrm{PkM}$, dan (f) pengurusan izin melaksanakan kegiatan pengabdian, baik di kalangan internal institusi maupun pihak eksternal terkait.

2. Tahap pendidikan dan pelatihan. Pendidikan dan pelatihan yang dilaksanakan berupa kegiatan IST. Topik-topik pendidikan dan pelatihan pada tahapan ini antara lain sebagai berikut:

a. Analisis permasalahan pembelajaran yang telah dilaksanakan sebelumnya.

b. Konsep penelitian dan pelaksanaannya.

c. Penelitian tindakan kelas.

d. Instrumen penelitian yang dibutuhkan.

e. Teknik analisis data hasil `penelitian.

f. Teknik penyusunan laporan penelitian,

g. Penulisan artikel dan publikasi ilmiah.

3. Tahap workshop kelompok guru. Tahap ini berupa kegiatan OST, yaitu memberikan pendampingan kepada guru mitra dalam melaksanakan kegiatan penelitian dan penulisan serta publikasi karya ilmiah. Kegiatan ini dilaksanakan oleh guru mitra bersama tim PkM sesuai mata pelajaran yang diajarkan dan kualifikasi bidang keahliannya.

4. Tahap monitoring, evaluasi dan pelaporan. Kegiatan pada tahapan ini dimaksudkan untuk mengevaluasi keseluruhan kegiatan pengabdian sehingga dapat diketahui hasil, permasalahan atau kendala yang muncul, faktor yang mendukung dan menghambat serta solusi pemecahannya. Kegiatan ini dilakukan secara berkala dari pelaksanaan kegiatan penelitian sampai didapatkan hasil atau produk berupa laporan penelitian dan artikel ilmiah. Keseluruhan kegiatan selanjutnya dibuatkan dalam bentuk laporan akhir kegiatan pengabdian.

\section{HASIL DAN PEMBAHASAN}

Mitra dalam kegiatan ini adalah semua guru mata pelajaran di MAN 3 Lombok Tengah sebanyak 48 orang. Tinginya animo guru dalam mengikuti kegiatan pelatihan menunjukkan bahwa guru memiliki kesadaran untuk lebih memahami dan dapat melakukan penelitian tindakan kelas, serta membuat laporan dalam bentuk karya ilmiah yang dapat di publikasikan pada jurnal ilmiah. Animo mitra tersebut ditunjukkan oleh partisipasi mitra dalam pelaksanaan kegiatan PkM ini yang terdiri atas partisipasi pihak sekolah (pengelola/manajemen) dan partisipasi guru. Bentuk partisipasi yang dilakukan oleh pihak sekolah adalah: (1) penyediaan tempat pelaksanaan kegiatan, (2) penyediaan sarana yang dibutuhkan selama pelaksanaan kegiatan, dan (3) bersama tim PkM melaksanakan kegiatan monitoring dan evaluasi proses pelaksanaan dan produk kegiatan yang dihasilkan guru selama proses PkM. Bentuk partisipasi guru mitra antara lain adalah: (1) menghadiri setiap kegiatan sesuai jadwal yang telah disepakati dan ditetapkan, (2) menyiapkan perangkat pembelajaran yang digunakan dalam kegiatan penelitian, (3) menyiapkan semua sarana berupa alat dan bahan atau dalam bentuk lainnya yang digunakan dalam pembelajaran sebagai implementasi pelaksanaan kegiatan penelitian, (4) berpartisipasi dalam keseluruhan proses pelatihan dan pendampingan selama kegiatan pengabdian berlangsung.

Tahap persiapan yang meliputi menyusun ToR; identifikasi calon peserta; pertemuan internal tim pengabdian untuk penentuan waktu pelatihan, tempat, dan materi; dan pengurusan izin melaksanakan kegiatan pengabdian dilakukan selama 2 (dua) minggu sejak tanggal 1-14 Agustus 2018. Kegiatan yang dilakukan pada tahap persiapan yaitu mempersiapkan peserta dan administrasi kegiatan, persiapan internal juga dilakukan di mana dalam ToR, tim pengabdian secara rutin bertemu untuk mendiskusikan materi kegiatan.

\section{Penyampaian konsep tentang analisis permasalahan pembelajaran}

Konsep analisis permasalahan pembelajaran disampaikan pada kegiatan pendidikan dan pelatihan dengan tujuan agar guru dapat menganalisis dan menemukan permasalahan-permasalahan yang terjadi selama pembelajaran yang telah dilaksanakan sebelumnya. Adanya permasalahan yang muncul sebagai hasil analisis dijadikan sebagai rumusan permasalahan yang akan dicarikan solusi untuk perbaikan, yang selanjutnya dijadikan topik penelitian.

Dalam menemukan permasalahan pembelajaran, guru mitra menganalisis perangkat pembelajaran yang telah digunakan. Menurut hasil diskusi antara tim PkM dengan guru mitra, hal yang paling mungkin dilakukan untuk 
analisis permasalahan pembelajaran adalah dengan mengkaji perangkat yang telah ada dan dikaitkan dengan implementasi yang telah dilakukan. Hal ini senada dengan pendapat Retnaningsih, Maasawet, dan Boleng (2017) yang menyatakan bahwa menyusun dan mengembangkan perangkat pembelajaran dengan baik merupakan salah satu keterampilan guru. Perangkat pembalajaran memudahkan guru pada proses pembelajaran karena setiap tahapan yang dilakukan siswa terkondisikan dengan baik sehingga hal tersebut diharapkan mampu membuat suasana yang menyenangkan di dalam kelas.

Hasil diskusi tim PkM dengan guru mitra menunjukkan bahwa selama pembelajaran siswa bersikap pasif, cenderung menerima apa adanya sebagaimana materi yang disampaikan oleh guru, bertanya ataupun menjawab pertanyaan hanya terjadi pada sebagian kecil siswa. Fenomena seperti ini juga terjadi di sekolah lainnya sebagaimana hasil pengamatan Retnaningsih et.al. (2017) yang menyatakan bahwa proses pembelajaran yang dilakukan di kelas masih menggunakan pembelajaran konvensional, ceramah dan penugasan. Hal ini menyebabkan siswa kurang terlibat aktif dalam proses pembelajaran. Hal tersebut menjadikan siswa malas-malasan dalam belajar, keterampilan yang dimiliki tidak bisa disalurkan secara maksimal, kurang percaya diri dan tidak mandiri. Fakta ini bertolak dengan tujuan pembelajaran, khususnya bidang Ilmu Pengetahuan Alam, yang berperan penting dalam usaha menciptakan manusia yang berkualitas untuk dapat bersaing dengan perkembangan zaman dan teknologi.

\section{Penyampaian konsep tentang penelitian tindakan kelas}

Pada tahap ini, tim PkM memberikan pemahaman tentang PTK yang meliputi konsep, desain, dan contohcontoh implementasi penelitian dalam PTK. Konsep dan desain tentang PTK yang disampaikan kepada guru mitra merujuk pada konsep dan desain yang dikembangkan oleh Pujiono (2008). Pelaksanaan kegiatan ini dimaksudkan agar guru mitra dapat memahami dengan baik konsep PTK dan desainnya, sehingga dapat memilih dan melaksanakan PTK secara benar.

Konsep dan desain Pujiono (2008) menjadi acuan dari berbagai model penelitian tindakan kelas. Komponen pokok dalam penelitian tindakan kelas Kurt Lewin yang diuraikan oleh Pujiono (2008) adalah: (1) perencanaan (planning) (2) tindakan (acting) (3) pengamatan (observing) (4) refleksi (reflecting). Konsep dasar yang diperkenalkan oleh Kurt Lewin dikembangkan oleh Kemmis \& Mc. Taggart. Komponen tindakan (acting) dengan pengamatan (observing) disatukan dengan alasan kedua kegiatan itu tidak dapat dipisahkan satu sama lain karena kedua kegitan haruslah dilakukan dalam satu kesatuan waktu. Kegiatan observasi harus dilakukan sesegera mungkin setelah berlangsungnya suatu kegiatan (Sumini, 2010).

\section{Penyampaian konsep tentang metode penelitian (desain, instrumen dan analisis data)}

Konsep metode penelitian dalam PTK juga sangat penting untuk disampaikan kepada guru mitra agar memiliki pemahaman tentang bagaimana melaksanakan PTK, pemilihan desain, penyusunan rancangan dan prosedur penelitian, penentuan subjek penelitian, penyusunan instrumen penelitian, dan teknik pengumpulan data dan analisisnya. Hal ini sesuai dengan pendapat Sudarsono (1997) tentang konsep PTK yaitu (1) merancang model PTK sesuai dengan permasalahan, rencana kegiatan, tindakan dan keadaan atau situasi kelas, (2) mengatur langkah-langkah tindakan yang akan dilakukan, (3) melakukan identifikasi komponen-komponen pendukung yang diperlukan, (4) melakukan pengaturan dan penyusunan jadwal kegiatan yang akan dilakukan, (5) menyusun rancangan tindakan sesuai dengan model penelitian tindakan kelas dan jadwal kegiatan. Langkah berikutnya setelah selesai dalam penyusunan desain dan prosedur adalah menerapkan atau melaksanakan tindakan sesuai dengan rencana yang telah ditetapkan

\section{Penyampaian konsep tentang penulisan laporan penelitian}

Laporan penelitian sangat penting untuk disampaikan kepada guru mitra sebagai luaran utama kegiatan PkM yang harus dihasilkan oleh guru mitra sesuai dengan mata pelajaran yang diajarkannya. Konsep yang disampaikan meliputi komponen laporan, yaitu teknik penyusunan latar belakang, merumuskan masalah, menetapkan tujuan dan manfaat penelitian, kajian teori, metode penelitian, hasil dan pembahasan, kesimpulan penelitian, dan teknik peyusunan daftar pustaka.

\section{Penyampaian konsep tentang penulisan artikel ilmiah}

Penulisan artikel ilmiah menjadi luaran tambahan bagi guru mitra, luaran wajib diperuntukkan bagi guru mitra yang mengajarkan mata pelajaran matematika, biologi, fisika, dan kimia, sesuai dengan kualitifikasi tim PkM. Kegiatan ini berisi penyampaian konsep penulisan artikel ilmiah meliputi abstrak, pendahuluan, metode, hasil dan pembahasan, kesimpulan, saran dan rekomendasi, serta daftar pustaka. 
Tabel 2. Hasil pelaksanaan kegiatan IST

\begin{tabular}{|c|c|c|c|c|}
\hline No & Materi & Hasil yang Dicapai & \% Tingkat Pemahaman Guru & Kelemahan yang Dialami Guru \\
\hline 1. & $\begin{array}{l}\text { Analisis } \\
\text { permasalahan } \\
\text { pembelajaran }\end{array}$ & $\begin{array}{l}\text { Guru mendapatkan berbagai permasalahan yang dialami selama } \\
\text { pembelajaran, baik yang tampak pada siswa maupun yang dirasakan oleh } \\
\text { guru ketika proses mengajar, yaitu. } \\
\text { 1. Siswa pasif selama pembelajaran. } \\
\text { 2. Sebagian besar siswa tidak dapat menyelesaikan masalah dengan baik. } \\
\text { 3. Siswa lebih cenderung menerima materi yang diajarkan daripada } \\
\text { mengkonstruksi sendiri. } \\
\text { 4. Pembelajaran yang dilakukan oleh guru bersifat ekspositori, dengan } \\
\text { memberikan konsep, contoh, dan soal atau fenomena. } \\
\text { 5. Guru kurang memahami model dan implementasi secara utuh dalam } \\
\text { pembelajaran. }\end{array}$ & $\begin{array}{l}73,68 \% \text { guru dapat menganalisis } \\
\text { permasalahan pembelajaran yang } \\
\text { dapat diangkat sebagai } \\
\text { permasalahan penelitian. }\end{array}$ & $\begin{array}{l}\text { 1. kurang menyadari bahwa setiap } \\
\text { fenomena belajar siswa dapat } \\
\text { berpotensi sebagai masalah } \\
\text { penelitian. } \\
\text { 2. } \text { merasa canggung untuk } \\
\text { mengungkap permasalahan yang } \\
\text { dialami terutama dalam } \\
\text { mengajar, karena kekhawatiran } \\
\text { akan anggapan tidak dapat } \\
\text { mengajar dengan baik. }\end{array}$ \\
\hline 2. & $\begin{array}{l}\text { Konsep tentang } \\
\text { penelitian }\end{array}$ & $\begin{array}{l}\text { 1. Guru dapat memahami konsep penelitian. } \\
\text { 2. Guru dapat memahami perbedaan antara penelitian eksperimen } \\
\text { dengan PTK. }\end{array}$ & $\begin{array}{l}76,34 \% \text { guru dapat memahami } \\
\text { konsep penelitian dengan baik. }\end{array}$ & $\begin{array}{l}\text { Guru lebih mengetahui penelitian } \\
\text { eksperimen dari pada PTK, sesuai } \\
\text { dengan jenis penelitian ketika } \\
\text { menyelesaikan studi S-1. }\end{array}$ \\
\hline 3. & $\begin{array}{l}\text { Konsep tentang } \\
\text { metode penelitian: } \\
\text { desain, } \\
\text { instrumen dan } \\
\text { analisis data }\end{array}$ & $\begin{array}{l}\text { Guru memiliki pemahaman tentang metode penelitian meliputi desain, } \\
\text { instrumen, dan analisis data. }\end{array}$ & $\begin{array}{l}65,79 \% \text { guru dapat memahami } \\
\text { metode penelitian dengan baik. }\end{array}$ & $\begin{array}{l}\text { Analisis data terbatas sesuai } \\
\text { penilaian guru, tidak mengarah pada } \\
\text { analisis secara statistik. }\end{array}$ \\
\hline 4. & Konsep PTK & Guru lebih memahami secara mendalam tentang PTK. & $\begin{array}{l}89,47 \% \text { guru dapat memahami } \\
\text { konsep PTK dengan baik. }\end{array}$ & $\begin{array}{l}\text { 1. kurang memahami perbedaan } \\
\text { refleksi dan evaluasi. } \\
\text { 2. kesulitan untuk mendapatkan } \\
\text { pengamat selama pembelajaran. }\end{array}$ \\
\hline 5. & $\begin{array}{l}\text { Konsep penulisan } \\
\text { laporan penelitian }\end{array}$ & Guru memahami konsep dalam menulis laporan penelitian. & $\begin{array}{l}97,37 \% \text { guru memahami konsep } \\
\text { penulisan laporan dengan baik. }\end{array}$ & - \\
\hline 6. & $\begin{array}{l}\text { Konsep penulisan } \\
\text { artikel ilmiah }\end{array}$ & Guru dapat memahami konsep penulisan artiel ilmiah. & $\begin{array}{l}97,37 \% \text { guru memahami konsep } \\
\text { penulisan artikel ilmiah }\end{array}$ & - \\
\hline 7. & Publikasi ilmiah & $\begin{array}{l}\text { 1. Guru memahami pentingnya publikasi ilmiah. } \\
\text { 2. Kesepakatan bersama sebagai tim penulis dan failitas media publikasi. }\end{array}$ & $\begin{array}{l}100 \% \text { guru memahami pentingnya } \\
\text { publikasi ilmiah. }\end{array}$ & - \\
\hline
\end{tabular}


Tabel 3. Hasil pelaksanaan kegiatan OST

\begin{tabular}{|c|c|c|c|c|}
\hline No. & Materi & Hasil yang Dicapai & \% Tingkat Pemahaman Guru & Kelemahan yang Dialami Guru \\
\hline 1. & $\begin{array}{l}\text { Pendampingan } \\
\text { penyusunan } \\
\text { perangkat dan } \\
\text { instrumen. }\end{array}$ & $\begin{array}{l}\text { Guru memiliki perangkat pembelajaran dan instrumen } \\
\text { penelitian yang digunakan pada kegiatan penelitian. }\end{array}$ & $\begin{array}{l}78,95 \% \text { guru dapat menyusun dan } \\
\text { memiliki perangkat yang baik, dan } \\
\text { instrumen penelitian yang valid. }\end{array}$ & $\begin{array}{l}\text { Guru belum terbiasa menyajikan kegiatan } \\
\text { tiap sintak model ke dalam RPP sesuai } \\
\text { materi. }\end{array}$ \\
\hline 2. & $\begin{array}{l}\text { Pendampingan } \\
\text { pelaksanaan } \\
\text { kegiatan } \\
\text { penelitian. }\end{array}$ & $\begin{array}{l}\text { 1. Meningkatnya kemampuan guru dalam melaksanakan } \\
\text { penelitian tindakan kelas, karena dilalui dengan } \\
\text { pengalaman langsung. } \\
\text { 2. Guru mampu dan menjadi terbiasa melakukan evaluasi, dan } \\
\text { refleksi proses dan hasil pembelajaran, kemudian } \\
\text { menemukan solusi perbaikan dan mengimplementasikan } \\
\text { dalam pembelajaran pada setia tahap penelitian. }\end{array}$ & $\begin{array}{l}92,11 \% \text { guru data melaksanakan } \\
\text { kegiatan penelitian dengan baik dan } \\
\text { terstruktur. }\end{array}$ & $\begin{array}{l}\text { Pembelajaran yang dilakukan guru ada } \\
\text { pertemuan awal mengalami kesulitan } \\
\text { dalam mengelola kelas dengan baik } \\
\text { karena siswa tidak terbiasa dengan cara } \\
\text { belajar yang dilakukan. Guru juga } \\
\text { mengalami kesulitan dalam mengatur } \\
\text { penggunaan waktu sesuai yang tercantum } \\
\text { pada RPP. }\end{array}$ \\
\hline 3. & $\begin{array}{l}\text { Pendampingan } \\
\text { penulisan } \\
\text { laporan } \\
\text { penelitian. }\end{array}$ & $\begin{array}{l}\text { 1. Guru dapat menulis laporan penelitian. } \\
\text { 2. Guru memiliki laporan penelitian yang dapat dimanfaatkan } \\
\text { untuk kepentingan selanjutnya. }\end{array}$ & $\begin{array}{l}52,63 \% \text { guru dapat menulis laporan } \\
\text { penelitian dengan baik dan tepat } \\
\text { waktu. }\end{array}$ & $\begin{array}{l}\text { Guru mengalami kesulitan dalam akses } \\
\text { informasi yang dijadikan sebagai rujukan } \\
\text { pada kajian pustaka. Guru juga } \\
\text { mengalami kesulitan dalam menyusun } \\
\text { pembahasan ketika menghubungkan hasil } \\
\text { penelitian dengan kajian teori dan } \\
\text { empiris. }\end{array}$ \\
\hline 4. & $\begin{array}{l}\text { Pendampingan } \\
\text { penulisan } \\
\text { artikel ilmiah } \\
\text { terpublikasi. }\end{array}$ & $\begin{array}{l}\text { Guru dapat menulis artikel ilmiah. } \\
\text { Guru memiliki artikel terpublikasi pada jurnal (bentuk draf dan } \\
\text { proses pendampingan terus berlanjut sampai artikel } \\
\text { terpublikasi pada jurnal. }\end{array}$ & $\begin{array}{l}31,58 \% \text { guru yang tertarik menulis } \\
\text { artikel terpublikasi jurnal ilmiah. }\end{array}$ & $\begin{array}{l}\text { Guru telah merasa cukup dengan laporan } \\
\text { penelitian sebagai hasil utama sesuai } \\
\text { kebutuhan dalam pengajuan kenaikan } \\
\text { pangkat. }\end{array}$ \\
\hline
\end{tabular}




\section{Penyampaian konsep tentang publikasi ilmiah.}

Tim PkM memberikan materi tentang teknik atau strategi yang dilakukan untuk melakukan publikasi ilmiah pada jurnal ilmiah nasional. Tim PkM yang dilibatkan pada kegiatan ini adalah tim yang memiliki tugas sebagai pengelola jurnal yang ada di Institut Keguruan dan Ilmu Pendidikan (IKIP) Mataram khususnya Fakultas Pendidikan Matematika dan Ilmu Pengetahuan Alam.

Berdasarkan hasil pelaksanaan kegiatan pada tahap IST diperoleh gambaran keadaan guru MAN 3 Lombok Tengah yaitu (1) sebagian besar guru telah mampu menganalisis permasalahan yang dapat diangkat sebagai permasalahan utama pada kegiatan penelitian, (2) guru telah memahami dengan baik tentang konsep penelitian khususnya PTK, desain, instrumen, dan analisis data hasil penelitian, (3) guru telah mampu memahami konsep dan teknik penulisan laporan penelitian dan artikel ilmiah, dan (4) guru telah mampu memahami konsep dan teknik publikasi artikel pada jurnal ilmiah nasional (Tabel 2).

\section{OST Sebagai tindak lanjut IST}

Hasil pada Tabel 2 mengindikasikan bahwa kegiatan lanjutan berupa pendampingan pelaksanaan kegiatan penelitian, penulisan laporan dan penulisan artikel ilmiah untuk publikasi pada jurnal nasional dapat dilakukan melalui tahapan OST. Berdasarkan uraian hasil OST pada Tabel 3, dapat dinyatakan bahwa guru MAN 3 Lombok Tengah memiliki potensi untuk mengembangkan diri dalam melakukan penelitian dan menghasilkan karya tulis ilmiah. Hal ini terbukti selama pelaksanaan kegiatan pengabdian. Guru secara konsisten selalu mengikuti kegiatan dengan baik. Produk yang diharapkan dapat dihasilkan dengan baik walaupun perlu dilakukan penyempurnaan pada bagian tertentu. Namun, secara umum hasil tersebut telah memenuhi kriteria karya tulis ilmiah.

Capaian luaran dari guru mitra berupa laporan penelitian dan draf artikel ilmiah merupakan hasil kegiatan PkM. Sebanyak $83,33 \%$ guru menghasilkan laporan yang hanya sampai pada penyusunan laporan penelitian. Sebanyak $16,67 \%$ guru mitra (dari guru MIPA) menghasilkan luaran tambahan berupa artikel ilmiah yang akan dipublikasi pada jurnal ilmiah nasional. Draft artikel tersebut saat masih dalam proses telaah dan revisi sesuai rekomendasi pengelola jurnal.

\section{KESIMPULAN}

Kegiatan pengabdian kepada masyarakat yang melibatkan guru MAN 3 Lombok Tengah telah berjalan dengan baik sesuai dengan perencanaan. Kesimpulan dari serangkaian kegiatan IST adalah guru telah mampu menganalisis permasalahan yang dapat diangkat sebagai permasalahan utama pada kegiatan penelitian; guru telah memahami dengan baik tentang konsep penelitian khususnya PTK, desain, instrumen, dan analisis data hasil penelitian; guru telah mampu memahami konsep dan teknik penulisan laporan penelitian dan artikel ilmiah; dan guru telah mampu memahami konsep dan teknik publikasi artikel pada jurnal ilmiah nasional. Kesimpulan dari serangkaian kegiatan OST adalah guru memiliki potensi untuk mengembangkan diri dalam melakukan penelitian dan menghasilkan karya tulis ilmiah, karya ilmiah yang dihasilkan dapat dikategorikan baik, dan secara umum telah memenuhi kriteria karya tulis ilmiah.

Pihak sekolah dan guru disarankan untuk meningkatkan kolaborasi antara sesama guru untuk saling memfasilitasi agar kegiatan penelitian dapat berjalan secara maksimal dan semua guru diharapkan secara berkelanjutan dapat melakukan kegiatan serupa dengan mandiri.

\section{UCAPAN TERIMA KASIH}

Kegiatan PkM ini dibiayai oleh Lembaga Penelitian dan Pengabdian Masyarakat IKIP Mataram melaui Program Hibah Internal Penelitian dan Pengabdian Masyarakat. Pihak lain yang mendukung kegiatan ini adalah sekolah MAN 3 Lombok Tengah yang telah bersedia menjadi mitra.

\section{DAFTAR PUSTAKA}

Hunaepi, Prayogi, S., Samsuri, T., Firdaus, L., Fitrini, H., \& Asy’ari, M. (2016) Pelatihan penelitian tindakan kelas (PTK) dan teknik penulisan karya ilmiah bagi guru di MTS. NW Mertaknao. Lumbung Inovasi, Jurnal Pengabdian pada Masyarakat, 1(1), 38-40.

Kementerian Pendidikan dan Kebudayaan. (2013). Peraturan menteri pendidikan dan kebudayaan nomor 69 tentang kerangka dasar dan struktur kurikulum sekolah menengah atas/madrasah aliyah. Jakarta: Kementerian 
Pendidikan dan Kebudayaan.

Muhali, Prayogi, S., Asy’ari, M., Hunaepi, Sukarma, I. K., Mirawati, B., Samsuri, T., Firdaus, L., \& Herdiana F. (2019). Pelatihan guru MAN 3 Lombok Tengah dalam menyusun perangkat pembelajaran yang melatihkan kemampuan metakognisi siswa. Baktimas: Jurnal Pengabdian kepada Masyarakat, 1(1), 49-60. http://dx.doi.org/10.32672/btm.v1i1.1182

Muslich, M. (2011). Melaksanakan PTK Itu Mudah. Jakarta, Indonesia: Bumi Aksara.

Prayogi, Sukarma, I. K., \& Muhali. (2016). IbM kelompok guru Madrasah Aliyah yang mengembangkan perangkat pembelajaran untuk melatihkan kemampuan berpikir kritis siswa (Laporan IbM). Mataram: LPPM IKIP Mataram.

Pujiono, S. (2008). Desain penelitian tindakan kelas dan teknik mengembangkan kajian pustaka. Makalah dipresentasikan pada Workshop Action Research untuk Guru-guru di MAN 1 Yogyakarta. Diperoleh dari: http://staff.uny.ac.id/sites/default/files /tmp/1.\%20PPM\%20Makalah\%20MAN\%20\&\%20UNY.pdf

Retnaningsih, W. S., Maasawet, E. T., \& Boleng, D. T. (2017). Analisis permasalahan guru dan siswa terkait perangkat pembelajaran IPA biologi berbasis inquiry dan keterampilan penulisan laporan ilmiah. Jurnal Pendidikan: Teori, Penelitian, dan Pengembangan, 2(4), 531-534.

Sudarsono. (1997). Pedoman pelaksanaan penelitian tindakan kelas (PTK): Bagian kedua. Jakarta, Indonesia: Dirjen Dikti Proyek Pendidikan Tenaga Akademik Bagian Pengembangan Pendidikan Guru Sekolah Dasar.

Sumini. (2010). Penelitian tindakan kelas dan pengembangan profesi guru. Jurnal Historia Vitae, 24(1), 14-30.

Sukaisih, R., \& Muhali. (2014). Meningkatkan kesadaran metakognitif dan hasil belajar siswa melalui penerapan pembelajaran problem solving. Jurnal Pengkajian Ilmu dan Pembelajaran Matematika dan IPA "Prisma Sains", 2(1), 71-82.

Sukaisih, R. dan Verawati, N. N. S. P. (2015). Penerapan model guided inquiry dilengkapi penilaian portofolio untuk meningkatkan aktivitas dan hasil belajar fisika siswa. Di dalam M. Ibrahim, Suyono, B. Jatmiko, W. Widodo, Z. A. I. Supardi (Editor), Pembelajaran dan Penilaian Sains Sesuai tuntutan Kurikulum 2013. Prosiding Seminar Nasional Tahun 2015 (pp. 268-271). Surabaya, Indonesia. 